KELAM ARAŞTIRMALARI 12:1 (2014), ss.13-24.

\title{
THE WAY OF COPING WITH THE CLASHING IDENTITIES: FROM NEO-ORIENTALISM TO THE ANTHROPOLOGY OF MUSLIMS IN THE WEST*
}

\author{
Prof.Dr.Şaban Ali Düzgün \\ duzgun@ankara.edu.tr
}

\begin{abstract}
From the very beginning Islam and naturally Muslims have lived as fragmented entities in many parts of the world. As it is historically known, soon after the death of the prophet Muhammad the expansion of Muslims' territorial dominance started. Although they were ruling elite and had territorial dominance, they lived as minority among other faiths and cultures and developed reflexes to survive among others. Currently they are experiencing similar conditions in many parts of the world including Europe with the exception that they do not have this territorial supremacy any more. Furthermore, they have to cope with such issues as identity, immigration, ethnicity, race, etc. With their strong religious sentiments Muslims do not have to entirely submit themselves to prevailing cultural codes, instead they need to treat these lands as free market of religions and cultures, and under the impact of modern and contemporary issues they need to develop a new mindset of contemporary Islam, individualized and voluntaristic. Within this new frame, Islam becomes something Muslims voluntarily join, rather than a tradition in which they live unless they choose to have it that way. This critical process makes Muslims active partners in the life they lead and in the thought they have in their mind. Only this kind of understanding can be competitive and far-reaching. Apart from this self-image of Muslims, the west has also to develop a new frame to evaluate situation of Muslims in their land which requires the Westerners to review the traditional orientalist approach and develop an anthropological one instead, which will deeply be dealt with in this paper.
\end{abstract}

Key Words: Clashing identities, neo-orientalism, anthropology, Muslims in the West/Europe.

A.Some Preliminary Paradigmatic Postulations

* Zagreb İslam Toplumu'nun Avrupa'da Müslümanlar Sempozyumuna Sunulan tebliğ, 2012. Sempozyum aynı adla kitaplaştırılmıştır. 
In order to tackle our subject-matter systematically, we propose to begin with some paradigmatic statements which are perhaps more familiar and more easily susceptible of analysis:

1. When compared with five decades ago religions are back. Those who predicted 50 years ago religions would disappear from individual and social life as a result of urbanization and secularization turned out to be wrong. Currently with all its institutions religions are back. But the crucial question remains: is that a good or bad news? One way of making this a good news for all is to be offered in this paper as transforming neoorientalist understanding of religions into anthropological one, the details of which will soon be tackled.

2. In their $1400^{\text {th }}$ years, religion starts activating like an active volcano. Historically this was the case for all religions. Islam now is the most active religion in the world, and so is Muslim world. In its $1400^{\text {th }}$ years Islam is following this tradition and while all others are dormant, Islam has recently been very active and dynamic. This activity and energy needs to be channeled correctly, and this paper will offer anthropological approaches rather than neo-orientalist one to find a good channeling for that.

3. Islam founded its civilization not in the lands it was born but in the lands it migrated. This is the tradition we have witnessed in the history of religions. To illustrate, Judaism was born in Egypt, but there has been no any Jewish civilization there. Christianity was born in Jerusalem; however, we have never had a Christian civilization there. Similarly, although Islam was born in Mecca we have never had an Islamic civilization in Hijaz territory. Bagdad, Samarqand, Damascus, Cordoba and Istanbul were the cultural centers of Islam. The crucial question remains here is that: Is Islam able to establish a new civilization in the lands it emigrates in modern times? Can Islam manage to harmonize Western culture with Islam's universalistic and humanistic values to create a novel civilization? This question is crucial more than ever as the Europe has been losing its transformative power in many fields.

4. In current dynamic debates Islam appears with some facets. In Muslim side two facets or characteristics of Islam come forth; one is logocentric character while the other is nomocentric. The intellectual or scholarly character of Islam corresponds to its logocentric face. Logocentric character of Islam appears at the same time as Islam of truth, whereas the nomocentric character of Islam comes out as Islam of identity, as it was emphasized by Abdulkarim Soroush. While the former is value oriented, universalistic and open minded, the latter propagates a closed society model and 
stereotyping itself. Whereas the former rejects every kind of monopoly, the latter supports it.

To clarify this rejection of monopoly two pivotal verses from the Holy Qur'an can be mentioned. The Holy Qur'an starts with a universalistic approach which implies rejection of former religions' claims of monopoly. The opening chapter of the Qur'an, Surah Fatiha, gives the clues of this universalism: Alhamdu lillahi rabbi'l-'alemin : praise be the Lord of the worlds. The emphasis underlined here is 'alemin: the worlds, not just one world and its members. In order remind us this universalistic stance the Holy Qur'an underlines this point again when it finishes: Kul e 'uzü bi-Rabbi'n-nâs: say: I seek refuge to the Lord of the People.

And Muslims in their daily prayer send their blessings to other faithful by reciting the following piece: Allahumme salli 'ala Muhammedin kemâ sallayte 'alâ İbrâhime ve 'alâ âl-i İbrâhim: O our God! Send your blessings to the generation of Muhammad as you sent to the Generation of Abraham and his generation. This is the basic model which sheds light on Muslim's approach to others believers.

With this logocentrism that calls others for creating common good e.c. ma'rûf, Islam could be able to prompt a sui generis civilization ( 'irfân) in any Western land. One needs to keep in the mind that civilization/ irfân requires compound contribution that is $m a$ 'rûf as it was underlined in Surah Hucurât: "We have created you as distinct people so that you could create a common good/ ma'rûf (verse, 13)."

The example of convivencia (Muslim Andalusian experience of different religions living together in peace and creating the common good together) is a model which shows us how different religions could create a 'common good'. In the mid and southern parts of Spain from 711 through 1492 lived a civilization and ironically produced this convivencia in the ages that were ironically called dark ages. Undoubtedly we today need this kind of experience far more than this, as there is nowadays barely a homogenous nation that is made up from one religion or one ethnic group. In the past there were countries called Christendom or dâr al-Islam (land of peace) with their pure Christian and Muslim population. What about the same countries now with other religious groups? Can we still define them as Christendom or dâr al-Islam? Are we still in a position of defending basic human rights just for us ignoring others?

5. In western scholarship two approaches have recently been developed to evaluate and understand Islam. One is called neo-orientalism or essentialism, while the second is called contingencist understanding of Islam and Muslims. The former is considering Islam and the Qur'an the only and unique basis for all actions of any 
Muslim, while latter takes Muslims' socio-economic and cultural conditions into account. The contingencist approach is anthropological one at the same time.

To show how neo-orientalism operates let's follow this quotation: Paul Perry, an anti-Islam writer and the author of recent book entitled Infiltration: How Muslim Spies and Subversives have penetrated Washington, reported recently that a Pentagon intelligence agency, the Counterintelligence Field Activity (CIFA), has embarked on a project to understand Islam by studying the Quran and the life of Prophet Muhammad, a typical essentialist position.

Under these paradigms we can now start analyzing how to handle the position of Muslims living in the West from two perspectives. One is neo-orientalist perspective while second is anthropological, which we will defend and support in this paper.

\section{B.NEO-ORIENTALIST AND ANTPROPOLOGY-BASED APPROACHES TO MUSLIMS: A CRITICAL COMPARISON}

It must be acknowledged that the history of Islam is the history of interpretations. Much of what is known as Islam is in reality nothing more than its historically and culturally interpreted form. There is no one-o-one overlapping between Islam and its historical phenomena. So any slander action arising from any Muslim must not be identified with Islam itself, which is an essentialist or neo-orientalist position in the West. It is misleading to cling to the idea that the behavior of Muslims through all centuries and countries can be explained primarily by reference uniquely to their belief system. On the contrary, anthropological and sociological studies are needed. Essentialists or neo-orientalists have discussed Islam but ignored Muslims.

Criticism of classical text-oriented orientalism now forces considering the demands of people living in the West rather than forcing them to live within a given structure. This is anthropological approach to the study of Muslims in the West that might be applicable. In this system the most serious part of solution is taking the people demands seriously.

It is high time the West considered a distinction between 'Islam and the West' and 'Muslims in the West', a distinction concentrating on solving Muslims' problems living there and thinking them as 'citizens' rather than 'minorities'.

Let's take a comparative look at the distinction between neo-orientalistic and anthropological approaches to Islam and Muslims in the West:

1. Neo-orientalism sees Muslims as minorities, while anthropological approach sees Muslims as citizens with basic rights and responsibilities 
The term minority is a modern and yet a discriminatory one by nature. However, it has an extensive usage in modern world and Muslims in the West have been treated as minorities and their rights and responsibilities are arranged accordingly. Nevertheless, its widespread and prevalent usage does not make it a prudent and sensible concept

The term 'minority' is to be transferred into citizen, with all rights and responsibilities. The model for that is the Medina period of Prophet Muhammad (pbuh). In the Medina Social Contract the Prophet entitles all members of different faiths as 'ummah', which is a political term, and means citizen.

2. Neo-orientalism sees Muslims as foreign to the West, whereas anthropological approach sees Muslims as constructive for the Western civilization

Neo-orientalist approach sees Islam as alien and foreigner to the Western territory. To them, Islam's glory days in Muslim Andalusia for almost 800 years and Sicily for almost 250 years were accidental. So neo-orientalists elapse these periods in European history.

Muslims are indispensable part of Western culture. In the cultural history of Western medicine Ibn Sina was seen as the body of medicine and Galen and Hippocrates were depicted as his two arms. Hayy b. Yaqzân by Ibn Tufail, er-Risâla al-Kâmiliyya by Ibn Nafîs, Risâlatu'l-Gufrân by Abu'la'lâ al-Ma'arrî and many other theological novels were the forerunners in humanities that would afterwards be followed in the West. Muslims in Andalusia created a life-dialogue model and togetherness, convivencia, to be pursued widely. Muslim writers within this fertile setting created thousands of stories; stories of courage and romance. When other nations were afraid of ideas, this civilization thrived on them, and kept them alive. When censors threatened to wipe out knowledge from past civilizations, this civilization kept the knowledge alive, and passed it on to others. It can be interesting to read what follows. In a review to David Levering Lewis' book God's Crucible: Islam and the Making of Europe, 570-1215, Joan Acocella notes the following:

"The Muslims came to Europe as 'the forward wave of civilization that was, by comparison with that of its enemies, an organic marvel of coordinated kingdoms, cultures, and technologies in service of a politico-cultural agenda incomparably superior' to that of the primitive people they encountered there. They did Europe a favor by invading. This is not a new idea, but Lewis takes if further: he clearly regrets that the Arabs did not go on to conquer the rest of Europe" this was "one of the most significant losses in world history and certainly the most consequential since the fall of the Roman Empire." 


\section{Neo-orientalism's motto is Islam and the West, on the contrary anthropology's motto is Muslims in the West}

The dichotomic distinction between Islam and the West implies a hegemony and exploitation. For the classification and definition of anything is the beginning of domination and control over the classified element, Islam in this case. Islam has historically and now been the subject of demean and humiliation.

The title 'Muslims in the West' gives the socio-economic and related factors precedence. Not the text but the context is to be blamed for any erroneous deed; not Islam but mistaken behaviors are to be targeted, which requires psychological and sociological analysis of the issue that concentrate the factors inciting individuals towards unexpected and unaccounted consequences. This approach precedes understanding rather than judging.

4. Neo-orientalists claim that Western civilization is unique, whereas anthropological approach says there might be other civilizations

Neo-orientalism regards Western modernity as the unique and only one human kind created at the end of linear-historical development and no one more will come up subsequent to it. This is also called rationalist tradition that does not leave room for any other alternative civilization, which is called as dependency thesis in the West. It puts Western example as the only one to be followed by non-Western societies. According to this thesis all endeavors will in the end lead to the Western style of modernity, i.e. if there are many roads to Rome, we have just one Rome.

Anthropological approach takes it for granted that different cultural milieus could create alternative modernities, which is at the same time the assertion of romantic tradition in the West and is called as post-colonial thesis. According to this thesis nonWestern societies have the capability of creating their sui generis and distinct modernity without following the footsteps of the Western one. This idea has ardently been defended by Talal Esed in his Anthropology \& the colonial encounter (edisyon), London: Ithaca Press, 1973.

5. Neo-orientalism claims monopoly, and so is dogmatic, whereas anthropological approach is cognitive and rational, ready to find a common ground among all

Neo-orientalism claims monopoly and control over such areas as reality, truth, religion, etc. It ignores the human capability that can interpret the Holy texts rationally and thus create a common denominator to lead a serene life for all. This claim of monopoly creates realms of conflict. 
Anthropological approach proposes a universal and value-based system. True religion presents its God not just an ultimate principle in itself but rather a God that assures everyone a serene life irrespective of their color, ethnicity and religiosity. Let me just mention two verses from the first and the last chapters from the Holy Qur'an reminding us this universal stance. In the beginning it is said 'Praise be to the Lord of the Worlds' and in the last 'Say I seek refuge to the Lord of the People'. The proclamation of 'The Lord of the worlds' and 'the Lord of the people' reject any monopoly and monolatry about God and sees the God as the guarantor for basic human rights for all as it sees Him as the Lord of all.

Islam takes it for granted that there are similarities and divergences among religions. Believing in One God and creating an ethical ground for our beliefs are among leading similarities. This common ground causes us to think that human kinds have a rational and intellectual capability of understanding and then constructing what is good for the people aside from divine authority. It is this rational and intellectual capability that makes it possible for human kind to question the truth-claims of religions. Even the least understandable elements in religion starts revealing themselves to our ratio and intellect the moment we start talking about them. Because talking about something means that it is discussible, understandable and explainable. That means every element in religion has also a rational ground that makes it explicable to us. So in Islam religion (theology) and reason (philosophy) are considered twin brothers as in the example of Ibn Rushd/Averroes as he is known in the West. That is the cognitive and realist aspect of the religion, which means that the religious message has an intrinsic understandable characteristic. What makes it possible for people from different religions come together and discuss the religious matters is this cognitive and realist structure of the religion.

This goes contrary to the understanding of Tertullianus who sees the distance between the two as the distance between Athens, the capital city of philosophy and Jerusalem, the capital city of religion, which does not make room for rational and cognitive interaction; on the contrary he leaves them to the control of dogma.

\section{What Can Be Done To Improve Muslims' Position in the West?}

- They need to develop an indigenous and effective European leadership which is able to cope with the issues competently and intellectually. This competence and intellectuality are required so that the categorization of Islam as a foreign 'cult' could be avoided.

- The stereotypical and clishéd negative image of Islam as 'other' must be transformed through proper use of the media into 'constructive other' or 'brother'. 
- Provocative anti-Christian polemics should be avoided lest they provoke strong racist feelings among Christians. Islam's theological call for a common ground must take the podium politically.

- Irrespective of their differences in denominations Muslims should attempt to reach more achievable goals by promoting co-operation among themselves instead of wasting their energy for homogenizing diverse Muslim ethnic or religious groups.

- Muslims should become involved in nationwide intellectual and social activities in order to overcome the powerful assimilative influence of the Western mainstream. They must pursue a value-oriented and universalistic understanding of Islam. Scholarly study of Islam has to be brought fore. It must not be forgotten that contemporary fundamentalism owes much of its success to Islam's scholarly vacuum.

- For a fine cooperation it is necessary to reduce some controversial debates. Over the last two decades Islam has become connected so many trivial hot debates like that overshadowed the real issues which would enable the native citizens to accept Muslim existence in the West.

- The best way of speaking about Muslims in Europe should be shifted from cultural differences to socioeconomic one. Public schools should teach the Islamic contributions that have led to modern Europe to show that Islam is not as foreign as some perceive. Newly educated Imams and teachers could promote a common ground in European countries. Indeed more than 2,600 mosques in Germany alone are due means of searching for a good common ground and bridging the gap between the members of different cultures and religions.

- As part of democracy culture both sides have to learn that the inability to hear one another may be the greatest problem of the Euro-Muslim debate. There have been and will be some provocative events like Danish cartoon incident that sparked some riots in Muslim countries. It will be wise to use legal means to show displeasure as a sign of belief in democratic institutions rather than these kinds of riots. It should be kept in mind that some symbolic events like minaret crisis foster more alienation in Muslim communities. Europeans intolerance is not restricted purely to Muslims but they became an easy target because of terrorism.

\section{Challenges Muslims Are Facing in the EU Countries}

Poverty and segregation: Muslims are more likely than the EU general population to be poor and live in segregated, crime prone neighborhoods according to a 2007 report from the Centre for European Policy Studies. It underlines the following:

- The position of Muslims is dictated by socioeconomic realities rather than cultural preferences. 
- There are also self-segregate Muslims for reasons like language barrier.

- To protect themselves some Muslims seek closed communities.

- High crime rates and dependency on the social welfare system cause Europeans to feel Muslim population as problems.

- The more Muslims involved with their religion, the less likely they participate in behaviors like drugs using and criminal activities.

- A French philosopher has recently said that next wars will be semantic. If you can impose the meaning you choose for words you have gained such wars. Unfortunately very serious semantic war has been conducted against Islam and Muslims all over the world, which creates clichés and stereotypes about Muslims.

The answers given to the following poll published in New York Times show how ignorant and prejudged people are about Islam and Muslims (I have only selected some questions):

1. Which holy book stipulates that a girl who does not bleed on her wedding night should be stoned to death?
a. Koran
b. Old Testament
c. (Hindu) Upanishads

2. Which holy text declares: "Let there be no compulsion in religion"?
a. Koran
b. Gospel of Matthew
c. Letter of Paul to the Romans

3. The terrorists who pioneered the suicide vest in modern times, and the use of women in terror attacks, were affiliated with which major religion?
a. Islam
b. Christianity
c. Hinduism

4. "Every child is touched by the devil as soon as he is born and this contact makes him cry. Excepted are Mary and her Son." This verse is from:

a. Letters of Paul to the Corinthians

b. The Book of Revelation

c. An Islamic hadith, or religious tale

5 . Which holy text is sympathetic to slavery?
a. Old Testament
b. New Testament
c. Koran 
6. Which holy text urges responding to evil with kindness, saying: "repel the evil deed with one which is better."

a. Gospel of Luke

b. Book of Isaiah

c. Koran ${ }^{1}$

\section{Conclusion}

Muslims in the West especially in Europe have recently been experiencing new challenges like soaring racism and far-right on political side; unemployment in economic side; fundamental tendencies among youth in social side, etc. These and similar issues need urgent handling which requires both Westerners and Muslims to interact, most of which have been numerated in the text.

Muslims in the West consider religion in their mindset a significant part of their daily lives and they are more likely to identify themselves by their religion before their nationality. But that does not prevent them from identifying themselves with the host country with higher intellectual values. Even some Muslims who are not particularly devout may be drawn to projecting a strong Islamic identity in response to feelings of isolation. As both Westerners and Muslims share some common ultimate concerns and intellectual values, it seems Muslims with their respective notes will contribute to Western song very much. This is similar to the case of Catholics. When they migrated to the States in 1930s many Americans rejected their coming as they were seen as a threat to Protestant values; however, none nowadays discusses their existence in the States.

It seems as humans we are very much in need of an ultimate authority like religion that will push us hard to value life over everything. And it is at that point that religion gains its real and effective meaning when it helps people to get rid of their personal whims and dedicate themselves to create the common good. In this regard religion does

1 http://www.nytimes.com/2010/10/10/opinion/10kristof.html

Answers:

1. b. Deuteronomy 22:21.

2. a. Koran, 2:256.

3. c. Most early suicide bombings were by Tamil Hindus (some secular) in

Sri Lanka and India.

4. c. Hadith. Islam teaches that Jesus was a prophet to be revered.

5. All of the above.

6. c. Koran, 41:34. Jesus says much the same thing in different words. 
not just present believers a pure metaphysical system but daily and timely principles that guide us a true interaction with others, i.e. a good life philosophy through life dialog, as well. True religion presents its God not just an ultimate principle in itself but rather a God that assures everyone a serene life irrespective of their color, ethnicity and religiosity. 